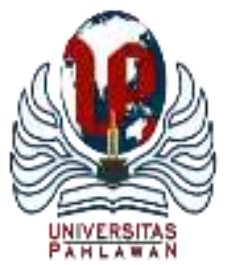

Edukatif : Jurnal Ilmu Pendidikan Volume 3 Nomor 6 Tahun 2021 Halm 3794 - 3801

EDUKATIF: JURNAL ILMU PENDIDIKAN

Research \& Learning in Education

https://edukatif.org/index.php/edukatif/index

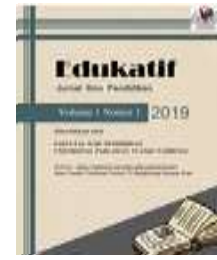

\title{
Hubungan Penggunaan Model Pembelajaran Blended Learning terhadap Hasil Belajar Matematika Siswa Sekolah Dasar
}

\author{
Riinawati ${ }^{\otimes}$ \\ Universitas Islam Negeri Antasari Banjarmasin, Indonesia \\ E-mail : riinawati@uin-antasari.ac.id
}

\begin{abstract}
Abstrak
Tujuan penelitian ini yaitu untuk mengetahui hubungan penggunaan model pembelajaran blended learning dan kesulitan yang dihadapi di SDN Padang Panjang Kabupaten Banjar. Metode penelitian pada penelitian ini menggunakan deskriptif kuantitatif. Penelitian ini dilakukan di SDN Padang Panjang Kabupaten Banjar dengan peserta didik SDN Padang Panjang Kabupaten Banjar sebagai subjek penelitian. Dalam penelitian ini yang dijadikan objek penelitian adalah hubungan penggunaan model pembelajaran blended learning terhadap hasil belajar peserta didik di SDN Padang Panjang Kabupaten Banjar. Populasi dalam penelitian ini adalah seluruh peserta didik kelas I sampai kelas VI di SDN Padang Panjang Kabupaten Banjar tahun ajaran 2020/2021 sebanyak 118 orang. Teknik sampel yang digunakan dalam penelitian ini menggunakan purposive sampling dan sampel penelitian ini ditetapkan di kelas V di SDN Padang Pajang Kabupaten Banjar, Kelas V dengan jumlah 14 siswa.. Hasil dari penelitian ini menunjukkan bahwa adanya hubungan penggunaan model pembelajaran blended learning terhadap hasil belajar matematika siswa di SDN Padang Panjang Kabupaten Banjar.
\end{abstract}

Kata Kunci: Model Pembelajaran, Blended Learning, Hasil Belajar, Matetamatika.

\section{Abstract}

The purpose of this study was to determine the relationship between the use of blended learning models and the difficulties faced at SDN Padang Panjang, Banjar Regency. The research method in this study uses descriptive quantitative. This research was conducted at SDN Padang Panjang, Banjar Regency with students from SDN Padang Panjang, Banjar Regency as research subjects. In this study, the object of research is the relationship between the use of blended learning models and the learning outcomes of students at SDN Padang Panjang, Banjar Regency. The population in this study were all students from class I to class VI at SDN Padang Panjang, Banjar Regency, for the 2020/2021 academic year as many as 118 people. The sampling technique used in this study used purposive sampling and the sample of this study was set in class V at SDN Padang Pajang, Banjar Regency, Class $V$ with a total of 14 students. The results of this study indicate that there is a relationship between the use of blended learning models and learning outcomes in mathematics. students at SDN Padang Panjang, Banjar Regency.

Keywords: Learning Model, Blended Learning, Learning Outcomes, Mathematics.

Copyright (c) 2021 Riinawati

$\square$ Corresponding author:

Email: riinawati@uin-antasari.ac.id

DOI : https://doi.org/10.31004/edukatif.v3i6.1083 
3795 Hubungan Penggunaan Model Pembelajaran Blended Learning terhadap Hasil Belajar Matematika Siswa Sekolah Dasar - Riinawati

DOI: https://doi.org/10.31004/edukatif.v3i6.1083

\section{PENDAHULUAN}

Pendidikan adalah usaha sadar dan terencana guna mewujudkan suasana belajar dan proses pembelajaran secara aktif untuk mengembangkan potensi peserta didik agar memiliki kecerdasan spiritual keagamaan, pengendalian diri, dan semua keterampilan yang dibutuhkan untuk dirinya masyarakat, bangsa dan Negara, dimana hal tersebut secara tersirat sudah menjadi tujuan pendidikan itu sendiri. Pendidikan merupakan proses yang diperlukan untuk menyeimbangkan dan menyempurnakan perkembangan individu dan masyarakat (Kholifah \& Buditjahjanto, 2016). Dibandingkan dengan pendidikan, penekanan pendidikan adalah pada transfer pengetahuan dan keahlian, serta kesadaran dan pembentukan kepribadian individu dan masyarakat (Herliana et al., 2015). Melalui proses ini, bangsa dan negara dapat benar-benar mempersiapkan masa depan yang cerah bagi bangsa dan negara dengan mewariskan nilai-nilai agama, budaya, ide dan keahlian kepada generasi berikutnya (Nurkholis, 2013). Tujuan pendidikan adalah untuk menunjukkan generasi penerus dan membentuk karakter budaya bangsa. Oleh karena itu, semua tantangan besar harus diatasi dan tanggung jawab bersama. Pendidikan bukan hanya tanggung jawab guru, tetapi juga tanggung jawab seluruh elemen masyarakat (PMK, 2020). Pendidikan merupakan sarana penting untuk meningkatkan kualitas sumber daya manusia (SDM) dalam menjamin keberlangsungan pembangunan suatu bangsa. dalam dunia pendidikan hasil belajar memepengaruhi prestasi akademik sekolah dan juga mempengaruhi prestasi siswa dalam jenjang pendidikan berikutnya (Novitayati, 2013).

Secara umum, Abdurrahman menggambarkan hasil belajar dan kemampuan yang diperoleh anak setelah belajar, yang menurutnya anak yang berhasil telah berhasil mencapai tujuan belajar dan mengajarnya (mardianto, 2012). Hasil belajar adalah perubahan tingkah laku siswa akibat belajar. Skiner dengan teori Kondisioning Operannya sebagaimana dikutip Gredler (1991: 172) mengatakan bahwa hasil belajar merupakan respon (tingkah laku) yang baru. Skinner mengatakan bahwa hasil belajar itu berupa "respon baru", tetapi pada dasarnya respon baru itu setara dengan perilaku baru (pengetahuan, sikap, keterampilan) (Amin, 2017). Dimyati dan Mudjiono (2006:34) juga menyatakan bahwa hasil belajar merupakan hasil interaksi antara kegiatan belajar dan kegiatan pendidikan. Mengajar dari sudut pandang seorang guru berakhir dengan proses evaluasi hasil belajar. Dari sudut pandang siswa, hasil belajar merupakan akhir pendidikan di puncak proses pembelajaran. Menurut Nana Sudjana (2009), aspek kualitas hasil belajar dipengaruhi oleh perubahan pengetahuan, sikap, perilaku, dan hasil belajar siswa yang tahan lama serta dapat digunakan sebagai dasar dalam mempelajari bahan berikutnya (Sjukur, 2013).

Perubahan perilaku terjadi ketika siswa menjadi mahir dalam banyak sumber daya yang disediakan dalam proses pendidikan dan pembelajaran. Area emosional dan psikomotorik dikategorikan ke dalam menghafal, memahami, aplikasi, analisis, sintesis dan kemampuan evaluasi, dan menerima, berpartisipasi, mengevaluasi, mengatur dan sifat tingkat hasil belajar dari area emosional. Sedangkan ranah psikomotor terdiri dari tingkat persepsi, daya tanggap, gerakan terbimbing, gerakan familiar, gerakan kompleks dan kreativitas.

Terkait dengan faktor-faktor yang ada, peran guru sangat berhubungan dalam meningkatkan hasil belajar peserta didik. Karena dari hasil pengamatan pada peserta didik kelas V di SDN Padang Panjang Kabupaten Banjar pada saat kegiatan pembelajaran berlangsung peserta didik banyak yang tidak serius dalam memperhatikan pembelajaran dan asik dengan kegiatan mereka masing-masing, sehingga banyak dari siswa yang berada didalam kelas hanya membuat kegaduhan, misalnya mereka mengobrol dengan teman, bermain, bahkan ribut sendiri didalam kelas. Adapun kendala yang dialami saat melakukkan pebelajaran secara online membuat banyak sekali perubahan, baik dari segi metode pembelajaran maupun dari segi penilaian. Hal ini juga tentunya memiliki banyak kendala yang dialami oleh guru maupun siswanya. Selama menjalani proses pembelajaran online, banyak para siswa yang mengalami kesulitan ketika melakukan pembelajaran secara online. diantaranya yaitu susahnya mengakses internet yang kurang memadai merupakan salah satu kendala 
yang cukup banyak dialami bagi para siswa ketika melakukan pembelajaran secara online. salah satu faktornya adalah ketersediaan sinyal yang kurang bagus diberbagai daerah, terlebih bagi siswa yang berada didaerah pedalaman yang masih susah sinyal. Kuota merupakan sumber masalah berikutnya, dimana jika tidak menggunakan wifi dirumahnya, maka siswa harus mengeluarkan uang lebih untuk membeli kuota internet. Pembelian kuota internet memiliki kendala apabila orang tua dari siswa tersebut sedang kesusahan, sehingga siswa kesulitan juga untuk membeli kuota internet. Proses untuk mengikuti pembelajaran secara online pun menjadi terkendala dan siswa menjadi tidak bisa fokus mengikuti pembelajaran jika sinyal terganggu akibat cuaca buruk dan lain sebagainya.

Sulit memahami materi akibat akses internet yang mengalami gangguan, maka proses pembelajaran pun menjadi terganggu, sehingga pemahaman siswa terhadap materi pun mengalami kesulitan. Jika siswa ketika belajar secara tatap muka langsung saja belum paham, apalagi jika belajar yang dilakukan dengan sistem online. Maka dari itu, siswa harus inisiatif belajar mandiri dan juga mencari sumber-sumber lain di internet untuk menambah pemahaman terhadap materi yang diajarkan. Belajar secara online ternyata tidak membuat siswa senang, tetapi malah sebaliknya. Siswa tidak suka belajar online karena guru lebih banyak memberikan tugas tetapi minim penjelasan dan juga materi.

Rasa malas dan sulit berkonsentrasi, belajar secara online justru malah menambah rasa malas dan juga sulit untuk berkonsentrasi bagi siswa. Selain karena sudah pusing sama tugas-tugas yang diberikan, siswa juga menjadi lebih banyak waktu untuk bermain gawai. Seperti bermain game dan youtube dibandingkan dengan belajar. Akibatnya muncul rasa malas yang sangat susah untuk dilawan dan juga sulitnya berkonsentrasi ketika belajar, terlebih ketika guru malah sering memberikan banyak tugas yang malah akan membuat siswa semakin bosan dan stress ketika belajar. Oleh karena itu, guru dituntut untuk mampu menciptakan kegiatan pembelajaran yang menarik perhatian peserta didik, kreativitas dan menyenangkan agar nantinya mereka memiliki hasil belajar yang memuaskan.

Berdasarkan hasil observasi pada peserta didik kelas V di SDN Padang Panjang Kabupaten Banjar, sikap peserta didik tentang cara guru mengajar dengan penggunaan media pembelajaran masih kurang baik karena disebabkan oleh kurangnya variasi dalam kegiatan mengajar sehingga dapat mempengaruhi hasil belajar peserta didik. Padahal apabila guru bersedia menggunakan cara mengajar dengan strategi pendekatan dengan alat bantu pembelajaran yang lebih bervariasi maka peserta didik akan memiliki sikap yang positif terhadap cara mengajar gurunya sehingga diharapkan peserta didik menjadi lebih bersemangat dalam mengikuti proses pembelajaran. Untuk itu guru bisa menentukan cara mengajar dengan strategi pendekatan dan alat bantu pembelajaran yang tepat agar peserta didik lebih mudah menerima materi pembelajaran dan tidak cepat jenuh sehingga hasil belajar siswa akan meningkat.

Diperlukan strategi pembelajaran khusus agar matematika lebih mudah dipahami siswa dan meningkatkan hasil belajarnya. Salah satu strategi pembelajaran yang dapat memanfaatkan teknologi informasi untuk meningkatkan aktivitas siswa dan memperlancar proses pendidikan dan pembelajaran adalah pembelajaran campuran. Blended learning adalah kombinasi karakteristik pembelajaran tradisional dan lingkungan pembelajaran elektronik. Blended learning menggabungkan aspek pembelajaran berbasis web (internet) dengan pembelajaran tradisional "tatap muka". Blended learning menggabungkan karakteristik pembelajaran tradisional dengan karakteristik lingkungan e-learning atau pembelajaran campuran. Ini menggabungkan aspek pembelajaran campuran seperti pembelajaran berbasis web, streaming video, komunikasi audio sinkron dan asinkron dengan pembelajaran "tatap muka" tradisional. Tujuan pengembangan blended learning adalah untuk menggabungkan karakteristik terbaik dari pembelajaran di kelas (face-to-face learning) dengan karakteristik terbaik dari pembelajaran online untuk meningkatkan pembelajaran mandiri aktif siswa dan mengurangi waktu tatap muka selama kelas. Oleh karena itu, tujuan penggunaan pembelajaran campuran dapat dirumuskan sebagai berikut. (2) Secara mandiri bermanfaat bagi guru dan siswa, memberikan peluang praktis dan realistis untuk menumbuhkan pembelajaran, (3) Menggabungkan manfaat pembelajaran 
3797 Hubungan Penggunaan Model Pembelajaran Blended Learning terhadap Hasil Belajar Matematika Siswa Sekolah Dasar - Riinawati

DOI: https://doi.org/10.31004/edukatif.v3i6.1083

tatap muka dan pembelajaran online, konstan bagi siswa Meningkatkan fleksibilitas (Khoiroh, 2018). Penerapan blended learning diharapkan peserta didik agar dapat memahami materi dengan lebih baik dan lebih aktif lagi dalam mengikuti pembelajaran, sehingga dapat meningkatkan hasil belajar peserta didik. Prinsip-prinsip blended learning yaitu komunikasi antara pertemuan pembelajaran tatap muka dengan komunikasi tertulis online. Konsep pembelajaran ini tampaknya cukup sederhana, tetapi penggunaannya lebih kompleks. Oleh karena itu, pendidik perlu meningkatkan kualitas pendidikan (W. Abdullah, 2018).

Guru dapat menggunakan pembelajaran dengan model pembelajaran campuran untuk menambah waktu belajar siswa. Hal ini memungkinkan siswa untuk mengulang materi. Siswa dapat meningkatkan penguasaan topik mereka dengan mengulangi materi berulang-ulang dan berlatih pertanyaan secara mandiri atau dalam kelompok. Pembelajaran campuran ini juga menyederhanakan dan mempercepat proses komunikasi nonstop antara guru dan siswa (Eklund, Kay, \& Lynch, 2003; Harry, 2007) (Sandi, 2005).

McGinnis (2005) menyajikan enam hal yang perlu diperhatikan dalam menerapkan pembelajaran Burendido dalam artikelnya. (2) Burendi juga melakukan pembelajaran harus dilaksanakan dengan sungguhsungguh. Siswa kemudian dapat dengan cepat beradaptasi dengan sistem PJJ dan menjadi lebih mandiri. (3) Bahan ajar yang diberikan harus ditingkatkan baik dari segi bentuk maupun isi. (4) alokasi waktu, pada ekspresi pertama 75:25, 75\% waktu mulai digunakan untuk pembelajaran online dan $25 \%$ digunakan. Penugasan tatap muka (5) tutorial 25\% diberikan kepada yang tertinggal. (6) pembelajaran burendido membutuhkan kepemimpinan dengan waktu dan perhatian untuk terus mengatasi bagaimana meningkatkan kualitas pembelajaran (Ibrahim, 2012).

Keuntungan dari pembelajaran campuran adalah guru dapat memanfaatkan kegiatan pembelajaran di dalam dan di luar kelas, memanfaatkan keterampilan untuk menambah pelajaran dan memberikan tema dan pertanyaan secara online dengan cara yang mengatur dan mengendalikannya. Pembelajaran tanpa komunikasi tidak mungkin dilakukan, sehingga guru dan siswa dapat membentuk (online) di dalam dan di luar kelas dengan membentuk kelompok diskusi yang memanfaatkan kemajuan teknologi pada zaman ini. Menghasilkan hasil yang memenuhi harapan baik guru maupun siswa. Dewey dan Moore (dalam Comey, dalam Sari, 2016) berpendapat bahwa komunikasi memegang peranan penting dalam proses pembelajaran dan merupakan kunci untuk menciptakan lingkungan belajar yang efektif (Wardani et al., 2018).

Pengembangan model belajar Blended Learning ini diharapkan mampu membuat sesuatu yang baru dalam pembelajaran khususnya pembelajaran dari. Model belajar ini difokuskan untuk membuat suatu pembaruan dari model belajar lama menjadi yang lebih baru sehingga nantinya memicu keaktifan para peserta didik dalam kegiatan pembelajaran. Selain itu juga, hasil akhir yang diharapkan adalah supaya mampu membuat suatu perubahan ke arah yang lebih baik untuk menambah pengetahuan untuk peningkatan kemampuan peserta didik. Adapun penelitian terdahulu yang membahas mengenai blended learning menyatakan jika suatu pembelajaran yang dilakukan secara tatap muka akan membuat siswa jauh lebih aktif dan termotivasi dalam belajar. Akan tetapi dengan kondisi lingkungan saat ini yang mengharuskan melakukan social distancing, maka diperlukan suatu gagasan baru agar pembelajaran tetap efektif dan efisien. Akhirnya muncullah suatu gagasan apakah model belajar blended learning ini dapat memberikan hasil yang baik jika diterapkan dalam metode daring sebagaimana penelitian sebelumnya. Dengan keuntungan yang telah di jelaskan, maka blended learning dirasa cukup efektif untuk dapat diterapkan di era pandemi saat ini.

Berdasarkan uraian di atas, maka peneliti tertarik untuk melakukan penelitian dengan judul Hubungan Penggunaan Model Pembelajaran Blended Learning Terhadap Hasil Belajar Matematika Siswa SDN Padang Panjang Kabupaten Banjar. Pentingnya penelitian ini dilakukan yaitu untuk mengetahui hubungan penggunaan model pembelajaran blended learning dan kesulitan yang dihadapi di SDN Padang Panjang Kabupaten Banjar. Penelitian ini nantinya diharapkan dapat meringankan tugas pendidik untuk membuat metode pembelajaran yang menarik, kreatif dan inovatif yang akan membuat para peserta didik lebih termotivasi untuk meningkatkan semangat belajar sehingga nantinya tujuan belajar itu sendiri dapat tercapai. 
3798 Hubungan Penggunaan Model Pembelajaran Blended Learning terhadap Hasil Belajar Matematika Siswa Sekolah Dasar - Riinawati

DOI: https://doi.org/10.31004/edukatif.v3i6.1083

\section{METODE PENELITIAN}

Penelitian ini dilakukan di SDN Padang Panjang yang beralamatkan di Desa Padang Panjang, Kecamatan Karang Intan, Kabupaten Banjar, Provinsi Kalimantan Selatan. Dengan peserta didik SDN Padang Panjang Kabupaten Banjar sebagai subjek penelitian. Dalam penelitian ini yang dijadikan objek penelitian adalah hubungan penggunaan model pembelajaran blended learning terhadap hasil belajar peserta didik di SDN Padang Panjang Kabupaten Banjar.

Populasi adalah keseluruhan subjek penelitian apabila seseorang ingin meneliti semua elemen yang ada dalam wilayah penelitian, maka penelitiannya merupakan penelitian populasi (Arikunto,S, 2019:173) (Raco, 2018). Populasi adalah sekumpulan unit yang karakteristiknya (sifatnya) dapat diselidiki, dan jika populasinya terlalu besar, peneliti harus memperoleh sampel (bagian dari populasi) untuk dipelajari. Oleh karena itu, populasi yang diteliti harus menjadi keseluruhan subjek, dan populasi itulah yang menjadi tujuan penelitian itu diterapkan (P. M. Abdullah, 2015). Populasi dalam penelitian ini adalah seluruh peserta didik kelas I sampai kelas VI di SDN Padang Panjang Kabupaten Banjar tahun ajaran 2020/2021 sebanyak 118 orang, untuk keterangan lebih jelas dilihat pada tabel berikut:

Tabel 1

Jumlah Populasi peserta didik di SDN Padang Panjang Kabupaten Banjar Tahun Ajaran 2020/2021

\begin{tabular}{ccccc} 
No & Kelas & Laki-laki & Perempuan & Jumlah \\
\hline 1. & I & 7 & 5 & 12 \\
\hline 2. & II & 9 & 8 & 17 \\
\hline 3. & III & 8 & 12 & 20 \\
\hline 4. & IV & 4 & 13 & 17 \\
\hline 5. & V & 17 & 13 & 30 \\
\hline 6. & VI & 11 & 11 & 22 \\
\hline \multicolumn{2}{c}{ Jumlah } & 44 & 58 & 102
\end{tabular}

Sampel adalah sebagian atau wakil populasi yang diteliti (Arikunto,S, 2019:174) (Raco, 2018). Teknik sampel yang digunakan dalam penelitian ini menggunakan purposive sampling (teknik sampling bertujuan) yang artinya pengambilan sampel tersebut dilakukan dengan pertimbangan tertentu (Arikunto,S, 2019:183 (gunawan I, 2016). Sampel penelitian ini ditetapkan di kelas V di SDN Padang Pajang Kabupaten Banjar, Kelas V dengan jumlah 14 siswa. Peneliti memilih satu kelas tersebut karena melalui pengamatan yang telah dilakukan oleh peneliti selama penelitian yang sering menggunakan pembelajaran blended learning adalah kelas V di SDN Padang Pajang Kabupaten Banjar. Peneliti juga mempertimbangkan efisiensi waktu agar para wali kelas tidak terganggu karena kehadiran peneliti, jadi yang diambil hanya satu kelas. Sedangkan metode penelitian pada penelitian ini menggunakan deskriptif kuantitatif (Musianto, 2002). Menurut Arikunto (2010:143) deskriptif kuantitatif dengan teknik kolerasi maka membuat deskriptif tentang situasi keadaan, kejadian yang mendapatkan makna dan implikasinya, kemudian diketahui dengan mendektesi sejauh mana relasi-relasi pada suatu faktor yang berkaitan dengan suatu faktor atau lebih faktor lain, sehingga dengan demikian diketahui tinggi rendahnya pengaruh (Raco, 2018).

Sementara itu, alat penggali data yang digunakan peneliti dalam memperoleh data ini menggunakan alat penggali data yaitu observasi, angket dan dokumentasi. Observasi diartikan sebagai pengamatan dan pencatatan secara sistematis terhadap gejala yang tampak pada objek penelitian. Pengamatan dan pencatatan ini dilakukan terhadap objek di tempat terjadi atau berlangsungnya peristiwa (Sumanto, 2010). Studi pustaka dan dokumentasi biasanya digunakan untuk memperoleh informasi yang berbentuk berbagai catatan berupa buku, leaflet, pamphlet, surat kabar, katalog, foto, video dan catatan lainnya yang data-datanya dapat dipertanggungjawabkan kebenarannya (Arif Amiruddin Jabbar, 2014). Kuesioner merupakan teknik pengumpulan data yang dilakukan dengan memberi seperangkat pertanyaan atau pernyataan tertulis kepada 
3799 Hubungan Penggunaan Model Pembelajaran Blended Learning terhadap Hasil Belajar Matematika Siswa Sekolah Dasar - Riinawati

DOI: https://doi.org/10.31004/edukatif.v3i6.1083

responden untuk dijawabnya. Kuesioner dapat berupa pertanyaan / pernyataan tertutup atau terbuka, dapat diberikan kepada responden secara langsung atau dikirim melalui pos atau internet (Sugiono, 2010).

Uji coba penggalian data dilakukan dengan uji validitas dan realibilitas agar semua pertanyaan dalam angket valid. Model analisis korelasi yang digunakan pada penelitian ini adalah Korelasi Product Moment sebagai berikut :

$$
r x y=\frac{N \Sigma X Y-(\Sigma X)(\Sigma Y)}{\sqrt{\left\{N \Sigma X^{2}-(\Sigma X)^{2}\right\}\left\{N \Sigma Y^{2}-(\Sigma Y)^{2}\right\}}}
$$

Sedangkan untuk mengukur reliabilitas peneliti menggunakan rumus Spearman Brown, sebagai berikut:

$$
r_{i}=\frac{2 r_{b}}{1+r_{b}}
$$

Cara penarikan kesimpulan dan untuk menjawab tujuan penelitian tentang hubungan penggunaan pembelajaran blended learning terhadap hasil belajar matematika di SDN Padang Panjang Kabupaten Banjar sebagai berikut :

Jika $\mathrm{r}_{\text {hitung }}>\mathrm{r}_{\text {tabel }}$ dengan taraf signifikan 5\%, maka hipotesis alternatif

Ha : Ada hubungan penggunaan model pembelajaran blended learning terhadap hasil belajar matematika siswa di SDN Padang Panjang Kabupaten Banjar, diterima

Ho : Tidak ada hubunngan penggunaan model pembelajaran blended learning terhadap hasil belajar matematika siswa di SDN Padang Panjang Kabupaten Banjar, ditolak.

\section{HASIL DAN PEMBAHASAN PENELITIAN}

Berdasarkan tabel diatas dapat dicari korelasi (rxy) dengan menggunakan korelasi product moment.Berikut ini tabel rincian uji coba validitas angket kreativitas guru di Sekolah Dasar Negeri Padang Panjang Kabupaten Banjar, dengan menggunakan Microsoft Excel dengan jumlah (N) 10 responden. Untuk menguji validitas menggunakan $\mathrm{r}$ tabel dari nilai-nilai $\mathrm{r}$ product moment dengan taraf signifikan $5 \%=0,632$.

Agar lebih mudah dalam perhitungan validitas tiap item butir angket, peneliti menggunakan Microsoft Excel, untuk membantu menentukan rhitung tiap butir angket dengan person correlation dengan jumlah $(\mathrm{N})$ 10 responden, yang kemudian dikonsultasikan kepada $\mathrm{r}$ tabel dari nilai $\mathrm{r}$ product moment dengan taraf signifikasi 5\%. Dari tiap soal uji coba angket yang telah dihitung dengan menggunakan Microsoft Excel, menyatakan bahwa angket seluruhnya valid. Dapat dilihat dari $r$ hitung $>r$ tabel dengan $\mathrm{N}$ (responden) 10, dan kemudian dikonsultasikan pada $\mathrm{r}$ tabel dari nilai $\mathrm{r}$ product moment dengan taraf signifikasi $5 \%=0,632$. Maka item angket tersebut valid, yang berarti layak digunakan dan angket yang digunakan benar-benar mewakili permasalahan penelitian yang ada dan dapat disebarkan kepada semua sampel yang akan diteliti.

Berdasarkan perhitungan dan analisis data maka dinyatakan adanya hubungan penggunaan model pembelajaran Blended learning di SDN Padang Panjang Kabupaten Banjar Sedangkan untuk kesulitan dalam hubungan penggunaan model pembelajaran Blended learning di SDN Padang Panjang Kabupaten Banjar terdapat sedikit kesulitan dalam hal penyebaran angket dan pengumpulan data dimana siswa di sekolah SDN Padang Panjang Kabupaten Banjar banyak yang masih belum memahami dalam hal pengisian angket. Dan hubungan penggunaan model pembelajaran Blended learning terhadap hasil belajar matematika peserta didik di SDN Padang Panjang Kabupaten Banjar dapat di simpulankan berdasarkan perhitungan rumus korelasi product moment diatas maka dapat diketahui bahwa nilai rhitung $=0,386$ kemudian dikonsultasikan pada rtabel dengan jumlah subyek penelitian sebanyak 30 responden pada taraf signifikan 5\% maka: Pada taraf signifikan $5 \%=0,386>0,361$.

Hal tersebut juga dikatakan dalam jurnal penelitian yang berjudul "Model Pembelajaran Blended Learning Terhadap Motivasi dan Hasil Belajar Siswa Kelas X SMA Negeri 1 Pitumpanua Kab.Wajo (Studi Pada Materi Pokok Sistem Periodik Unsur)" yang memperkuat tentang penggunaan model pembelajaran Blended Learning murid dituntut secara mandiri dalam belajar dengan berbagai pendekatan yang sesuai agar 
3800 Hubungan Penggunaan Model Pembelajaran Blended Learning terhadap Hasil Belajar Matematika Siswa Sekolah Dasar - Riinawati

DOI: https://doi.org/10.31004/edukatif.v3i6.1083

murid mampu mengarahkan, memotivasi, mengatur dirinya sendiri dalam pembelajaran. Blended Learning ini merupakan kombinasi dari pembelajaran berbasis web dan pembelajaran langsung, maka pembelajaran ini dapat diterapkan pada mata pelajaran apapun, dipengaruhi oleh perkembangan ilmu pengetahan dan teknologi yang pesat. Terdapat hubungan yang signifikan dibuktikan dengan hasil pengolahan data menggunakan uji hipotesis yang dilakukan dengan uji t menghasilkan thitung $>$ ttabel $=4.14>1,678$ pada $=0,05$. Dengan demikian dapat disimpulkan bahwa ada hubungan model pembelajaran Blended Learning terhadap motivasi dan hasil belajar siswa kelas X SMA Negeri 1 Pitumpanua (studi pada materi pokok Sistem periodik unsur) (Manggabarani et al., 2016). Sehingga terdapat kesesuaian penelitian yang dilakukan oleh peneliti dan juga penelitian terdahulu, bahwa penerapan model pembelajaran blended learning ini terbukti mampu meningkatkan motivasi belajar peserta didik. Hal tersebut dapat dilihat dari munculnya indikator-indikator motivasi belajar peserta didik setelah dilakukannya pembelajaran blended learning. Namun, ada beberapa keterbatasan dalam penelitian ini dalam hal pengambilan data. Keterbatasan tersebut muncul dari kesulitan peneliti dalam penyebaran angket dan pengumpulan data dimana siswa di sekolah SDN Padang Panjang Kabupaten Banjar banyak yang masih belum memahami dalam hal pengisian angket. Meskipun demikian, keterbatasan tersebut tidak terlalu menjadi penghambat bagi peneliti untuk terus melakukan penelitian dan memberikan gambaran metode pembelajaran yang menarik, kreatif dan inovatif yang dapat membuat para peserta didik untuk termotivasi dalam belajar di saat pandemi seperti ini.

\section{KESIMPULAN}

Berdasarkan data-data yang telah dikumpulkan dari hasil penelitian yang dilakukan sebagaiman telah diuraikan pada bab terdahulu, maka dapat ditarik bahwa adanya hubungan penggunaan model pembelajaran blended learning di SDN Padang Panjang Kabupaten Banjar. Terlihat adanya peningkatan motivasi belajar peserta didik dalam penggunaan model pembelajaran blended learning. Peserta didik juga memberikan perubahan hasil belajar selama diterapkannya model pembelajaran blended learning. Jadi, metode pembelajaran blended learning mampu meringankan tugas pendidik untuk membuat metode pembelajaran yang menarik, kreatif dan inovatif yang akan membuat para peserta didik lebih termotivasi untuk meningkatkan semangat belajar sehingga nantinya tujuan belajar itu sendiri dapat tercapai. Sedangkan untuk kesulitan dalam hubungan penggunaan model pembelajaran Blended learning di SDN Padang Panjang Kabupaten Banjar yaitu dalam hal penyebaran angket dan pengumpulan data dimana siswa di sekolah SDN Padang Panjang Kabupaten Banjar banyak yang masih belum memahami dalam hal pengisian angket. Selain itu juga peneliti ingin memberikan saran kepada pihak pendidik mengenai penelitian ini untuk menerapkan model pembelajaran blended learning saat melakukan proses pembelajaran daring karena sudah terbukti dengan adanya peningkatan motivasi belajar peserta didik saat menggunakan model pembelajaran blended learning

\section{DAFTAR PUSTAKA}

Abdullah, P. M. (2015). Living in the world that is fit for habitation: CCI's ecumenical and religious relationships.

Abdullah, W. (2018). Model Blended Learning Dalam Meningkatkan. Ejournal.Kopertais4, 7(1), 855-866. ejournal.kopertais4.or.id/madura/index.php/fikrotuna/article/download/3169/2359/

Amin, A. K. (2017). Kajian Konseptual Model Pembelajaran Blended Learning berbasis Web untuk Meningkatkan Hasil Belajar dan Motivasi Belajar. Jurnal Pendidikan Edutama, 4(2), 51-64.

Arif Amiruddin Jabbar, M. (2014). Analisis Visual Kriya Kayu Lame Di Kampung Saradan Desa Sukamulya Kecamatan Pagaden Kabupaten Subang. 38-40. repository.upi.edu

Gunawan I. (2016). KUANTITATIF Imam Gunawan. 29. 
3801 Hubungan Penggunaan Model Pembelajaran Blended Learning terhadap Hasil Belajar Matematika Siswa Sekolah Dasar - Riinawati

DOI: https://doi.org/10.31004/edukatif.v3i6.1083

Herliana, F., Supriyati, Y., \& Astra, I. M. (2015). Pengaruh Model Pembelajaran Berbasis Blended Learning Dan Motivasi Belajar Terhadap Hasil Belajar Fisika Siswa Sma. Prosiding Seminar Nasional Fisika (EJournal) SNF2015, IV, 61-66. http://snf-unj.ac.id/kumpulan-prosiding/snf2015/

Ibrahim, N. (2012). Meningkatkan Hasil Belajar Matematika Dengan Blended Learning Dan Motivasi Berprestasi Siswa. Perspektif Ilmu Pendidikan, 26(XVII), 95-102. https://doi.org/10.21009/pip.262.1

Khoiroh, N. (2018). Pengaruh Model Pembelajaran Blended Learning dan Motivasi Belajar Terhadap Hasil Belajar Siswa Kelas VIII SMPN 1 Gumukmas. Jurnal Penelitian Ilmu Pendidikan, 10(2), 97. https://doi.org/10.21831/jpipfip.v10i2.13986

Kholifah, S. N., \& Buditjahjanto, I. G. A. (2016). Pengaruh Model Pembelajaran Blended Learning Terhadap Hasil Belajar Dan Motivasi Belajar Siswa Kelas Xi Tei Pada Mata Pelajaran Komunikasi Data Dan Interface Di Smk Negeri 1 Jetis Mojokerto. Jurnal Pendidikan Teknik Elektro, 5(3), 975-982.

Manggabarani, A. F., Sugiarti, \& Masri, M. (2016). Pengaruh Model Pembelajaran Blended Learning Terhadap Motivasi dan Hasil Belajar Siswa Kelas X SMA Negeri 1 Pitumpanua Kab.Wajo (Studi Pada Materi Pokok Sistem Periodik Unsur). Jurnal Chemica, 17(2), 83-93.

Mardianto. (2012). Kajian Hasil Belajar. Psikologi Pendidikan, 39-40. http://repository.uinsu.ac.id/408/5/BAB II.pdf

Musianto, L. S. (2002). Perbedaan Pendekatan Kuantitatif Dengan Pendekatan Kualitatif Dalam Metode Penelitian. Jurnal Manajemen Dan Kewirausahaan, 4(2), 123-136. https://doi.org/10.9744/jmk.4.2.pp.123-136

Novitayati. (2013). pengaruh metode blended learning dan self regulated learning terhadap hasil belajar IPS di smk negeri 3 malang.

Nurkholis. (2013). Pendidikan dalam Upaya Memajukan Teknologi Oleh: Nurkholis Doktor Ilmu Pendidikan, Alumnus Universitas Negeri Jakarta Dosen Luar Biasa Jurusan Tarbiyah STAIN Purwokerto. 1(1), 2444.

PMK, K. (2020). Tantangan Pendidikan di Masa Pandemi, Semua Orang Harus Jadi Guru | Kementerian Koordinator Bidang Pembangunan Manusia dan Kebudayaan. 2024, 1-7.

https://www.kemenkopmk.go.id/tantangan-pendidikan-di-masa-pandemi-semua-orang-harus-jadi-guru

Raco, J. (2018). Metode penelitian kualitatif: jenis, karakteristik dan keunggulannya. https://doi.org/10.31219/osf.io/mfzuj

Sandi, G. (2005). Pengaruh Blended Learning Terhadap Hasil Belajar Kimia Ditinjau Dari Kemandirian Siswa. Jurnal Pendidikan Dan Pengajaran, 241-251.

Sjukur, S. B. (2013). Pengaruh blended learning terhadap motivasi belajar dan hasil belajar siswa di tingkat SMK. Jurnal Pendidikan Vokasi, 2(3), 368-378. https://doi.org/10.21831/jpv.v2i3.1043

Sugiono. (2010). Hubungan Antara Kegiatan Tadarus Awal Pelajaran Dengan Minat Belajar Al-Quran Siswa Di SMA Muhammadiyah 3 Gadung Surabaya. Metode Penelitian, 1, 47-63.

Sumanto. (2010). Pengumpulan Data. 1-51.

Wardani, D. N., Toenlioe, A. J. E., \& Wedi, A. (2018). Daya Tarik Pembelajaran Di Era 21 Dengan Blended Learning. Jurnal Kajian Teknologi Pendidikan (JKTP), 1(1), 13-18.

https://core.ac.uk/download/pdf/287323676.pdf 